\title{
Arsenic linked to a former mining activity in the Hunan province: distribution at the local scale and bacterial As(III) oxidation
}

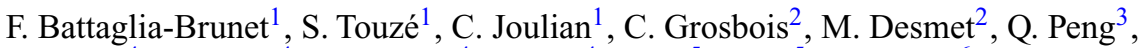

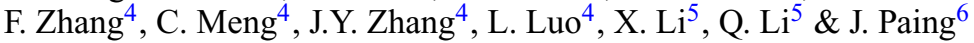 \\ ${ }^{1}$ BRGM, Orléans, France \\ ${ }^{2}$ University of Tours, Tours, France \\ ${ }^{3}$ ASEM Water Resources Research and Development Center, Changsha, Hunan, P.R. China \\ ${ }^{4}$ Hunan Agricultural University, Changsha, Hunan, P.R. China \\ ${ }^{5}$ Central South University, Changsha, Hunan, P.R. China \\ ${ }^{6}$ O-pure, Beaumont-la-Ronce, France
}

\begin{abstract}
The impact of a former small $\mathrm{Pb}-\mathrm{Zn}$ mine in Hunan (China) was studied in terms of arsenic (As) and metals concentrations in water streams and sediments, and from the perspective of biogeochemistry of As. Three water streams were characterized, two from galleries and one seeping at the base of the mine waste rocks dump. Contrary to the water from galleries, this last stream was acidic and contained relatively high As concentration. High As levels were also found in sediments downstream of the mine drainage flowing from the first gallery. Diverse As(III)-oxidizing bacteria were enriched and isolated from the mine sediments, some presenting ability to grow at low $\mathrm{pH}$ or in autotrophic conditions.
\end{abstract}

\section{INTRODUCTION}

Mining activities have caused major environmental problems on a global scale. Huge amounts of waste are generated when these geological materials are treated to extract the mining resources. Mine residues contain large fractions of sulfide materials that are vulnerable to oxidation when coming into contact with air and rainwater. These processes generate mine water containing a range of toxic metals and metalloids often including As (Johnson and Hallberg, 2005). Bioaccumulations and bioamplifications of this toxic element can lead to human intoxication, especially in fishing populations. Here, the distribution of the toxic element in different compartments of a small $\mathrm{Pb}-\mathrm{Zn}$ former mine site was considered. Then, As(III)-oxidizing bacterial strains that may be involved in remediation processes were enriched and isolated.

\section{METHODS}

\subsection{Site description and sampling}

The site is a small disused $\mathrm{Pb}-\mathrm{Zn}$ mine located in the region of Aotoushan, \#200 km southwest from Changsha, Hunan. The mine works include two galleries and one waste dump composed of coarse materials presenting visible sulfide crystals. Water flowed from two galleries and seeped at the base of the dump. The first gallery was located above the mine waste dump. The second gallery was in a discrete place, $300 \mathrm{~m}$ from the first gallery and the dump. The water flowing from the first gallery was discharged, at less partly, into the dump. Samples of water, bed sediments from the three water streams were collected in $200 \mathrm{~mL}$ sterile bottles. A sediment core was collected a few $\mathrm{km}$ downstream in a dam reservoir.

\subsection{Chemical analyzes}

At the laboratory, part of the samples was used to inoculate enrichment media, and the other part was devoted to chemical analyzes. Water phase was filtrated at $0.45 \mu \mathrm{m}$ and acidified with concentrated $\mathrm{HNO}_{3}$, then analyzed by ICP-MS. The solid phases were dried at $50^{\circ} \mathrm{C}$, crushed and analyzed using $\mathrm{X}$-ray fluorescence apparatus $\left(\mathrm{NITON}^{\circledR}\right)$.

\subsection{Enrichment and isolation of strains}

As(III)-oxidizing cultures were obtained by inoculating and sub-culturing the site samples in minimal medium CAsO1 (Battaglia-Brunet et al., 2002) at $\mathrm{pH}$ 3,5 and 6 , in autotrophic and heterotrophic (with $0.2 \mathrm{~g} \mathrm{~L}^{-1}$ yeast extract), in aerobic conditions. Three sub-cultures were performed, each being incubated for 3 weeks. Bacterial counting was performed by microscopy using a Thoma cell and by MPN technique for $\mathrm{As}(\mathrm{III})$-oxidizing microbes. Isolation was performed using the same medium but solidified with 
Table 1. Main characteristics of water streams.

\begin{tabular}{lcccc}
\hline & $\mathrm{pH}$ & $\begin{array}{l}\mathrm{As} \\
\mu \mathrm{g} \mathrm{L}^{-1}\end{array}$ & $\begin{array}{l}\mathrm{Pb} \\
\mu \mathrm{g} \mathrm{L}^{-1}\end{array}$ & $\begin{array}{l}\mathrm{Pb} \\
\mu \mathrm{g} \mathrm{L}^{-1}\end{array}$ \\
\hline Gallery 1 & 5.3 & 7 & 19 & 22.8 \\
Gallery 2 & 5.6 & 19 & 19 & 1.9 \\
Dump seepage & 3.1 & 373 & 865 & 2018 \\
\hline
\end{tabular}

agar. Strains recovered as colonies on the plates were screened for their ability to oxidize As(III). Purification of $\mathrm{As}(\mathrm{III})$-oxidizing strains is performed through five successive cultures on solid then liquid medium alternatively. Identification of the purified strains will be performed by sequencing their $16 \mathrm{~S}$ rDNA genes.

\section{RESULTS AND DISCUSSION}

\subsection{Arsenic and metals distribution in waters and sediments}

The water streams from galleries presented slightly acidic $\mathrm{pH}$ values, low $\mathrm{As}$ and $\mathrm{Pb}$ concentrations, but $\mathrm{Zn}$ concentrations higher than $1 \mathrm{mg} \mathrm{L}^{-1}$ (Table 1 ). In contrast, the dump seepage was more acidic a contained significant concentrations in As and heavy metals.

The surface sediment sampled in the mine drainage a few meters from the outlet of gallery 1 contained $2 \%$ As, $30 \%$ lead, $6 \%$ zinc and $20 \%$ total S. These solid materials are polluted by As- and metals-containing dust of sulfidic ores from the mine exploitation. They could contribute to As and metal concentrations in water and sediment downstream. As a fact, river sediments, a few km downstream the mine, were enriched in $\mathrm{As}, \mathrm{Pb}$ and $\mathrm{Zn}$ with a maximum peak at $8-10 \mathrm{~cm}$ deep (550 $\mathrm{mg} \mathrm{kg}^{-1}$ of As).

\subsection{Enrichment and isolation of bacterial strains}

The bacterial enrichment procedures focused on As(III)-oxidizing organisms produced five microbial communities, two at $\mathrm{pH} 3$ from the dump seepage (one autotrophic and one heterotrophic), one at $\mathrm{pH}$ 5 from the first gallery (heterotrophic), and two at pH 6 from the second gallery (one autotrophic and one heterotrophic). The highest proportion of As(III)oxidizing microbes was found in the heterotrophic enrichment from gallery 2 , where more than $10 \%$ of the cells were As(III)-oxidizing microbes. The isolation step resulted in a collection of strains from these enrichments. Isolation of strains from the first gallery
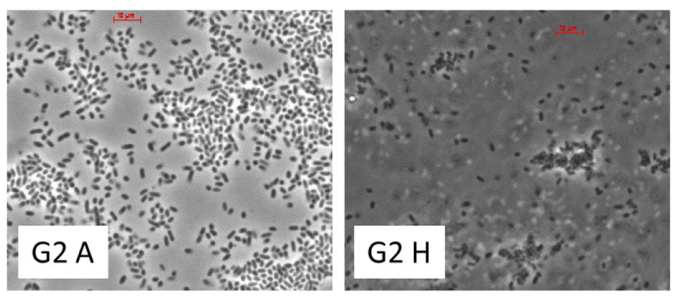

Figure 1. Strains from gallery 2 observed under an optical microscope $(\times 1000)$, G2 A: autotrophic; G2 H: heterotrophic.

was not efficient, with only one heterotrophic strain obtained. The waste seepage yielded five strains oxidizing $\mathrm{As}(\mathrm{III})$ at $\mathrm{pH} 3$, including one autotrophic. The enrichments from gallery 2 allowed the isolation of the highest number of As(III)-oxidizing strains, 65 colonies from the autotrophic medium, and 84 colonies from the heterotrophic medium (Fig. 1).

\section{CONCLUSIONS}

A range of As(III)-oxidizing strains were isolated from a Pb-Zn disused mine in Hunan. The availability of several strains from the dump seepage, able to grow and oxidize $\mathrm{As}(\mathrm{III})$ at $\mathrm{pH} \mathrm{3}$, present a particular interest for the development of bioremediation of acid mine drainages. The identification of the isolated strains will complete the characterization of the biodiversity of cultivable As(III)-oxidizing bacteria in the different water streams of the mine.

\section{ACKNOWLEDGEMENTS}

This research work has been performed in the frame of ATIM-Hunan project funded by the Region Centre Val de Loire, contract N 2015-00099715.

\section{REFERENCES}

Battaglia-Brunet, F., Dictor, M.C., Garrido, F., Crouzet, C., Morin, D., Dekeyser, K., Clarens, M. \& Baranger, P. 2002. An arsenic (III) - oxidizing bacterial population: selection, characterization, and performance in reactors. J. Appl. Microbial. 93(4): 656-667.

Johnson, D.B. \& Hallberg, K.B. 2005. Acid mine drainage remediation options: a review. Sci. Total Environ. 338(1-2): 3-14. 